九州大学学術情報リポジトリ

Kyushu University Institutional Repository

\title{
Reproduction in A Wild Population of the Korean Striped Field Mouse, Apodemus agrarius chejuensis
}

Oh, Hong Shik

Zoological Laboratory, Faculty of Agriculture, Kyushu University

Yoshinaga, Yuko

Zoological Laboratory, Faculty of Agriculture, Kyushu University

Mori, Takayuki

Zoological Laboratory, Faculty of Agriculture, Kyushu University

https://doi.org/10.5109/24228

出版情報：九州大学大学院農学研究院紀要. 42 (3/4)，pp.383-395，1998-03. Kyushu University バージョン：

権利関係 : 
J. Fac. Agr., Kyushu Univ., 43 (3•4), 383-395 (1998)

\title{
Reproduction in A Wild Population of the Korean Striped Field Mouse, Apodemus agrarius chejuensis
}

\author{
Hong Shik Oh, Yuko Yoshinaga and Takayuki Mōri* \\ Zoological Laboratory, Faculty of Agriculture, Kyushu \\ University, Fukuoka 812-8581, Japan \\ (Received December 2, 1997 and accepted December 3, 1997)
}

\begin{abstract}
A wild population of the Korean striped field mouse, Apodemus agrarius chejuensis, was investigated in the woods of Mt. Halla, Cheju Island, Korea. During the trapping period, from September 1994 to August 1996, population densities were high in the spring (April) and autumn (October), and declined in the winter (December to February). Males weighed over 35 $\mathrm{g}$ had descended testes during the breeding seasons, showing active spermatogenesis from March to November. By contrast, from December to February, spermatogenesis declined. In concerned to oogenesis, females weighed over $30 \mathrm{~g}$ captured from March to November had many Graafian follicles in their ovaries, while those captured from December to February had many primary and secondary follicles, occasionally with Graafian follicles which were in the atretic process. In the summer, since there were few pregnant females and critical decline was observed in the number of captured mice, parturition rates might decrease in July to August when the maximum temperature reached approximately $30^{\circ} \mathrm{C}$. Consequently, the seasonal breeding pattern of the investigated population of $A$. a. chejuensis was bimodal with high reproductive activities in the spring and autumn.
\end{abstract}

\section{INTRODUCTION}

Genus Apodemus are widely distributed in the Palaearctic and northern part of Oriental regions. In this genus, 14 species are known in the world, including two species in Korea and three species in Japan (Corbet and Hill, 1991). Of these species, the Korean striped field mouse, Apodemus agrarius, was the most abundant species among the rodents in Korea which inhabit fields from lowlands to woods in lower mountains (Hong and Lee, 1984).

In medical fields, this species has been known as a mediator of hemorrhagic fever with renal syndrome, and shows high mortality (Lee and Lee, 1976), particularly as a host of the Hantaan virus (Lee et al., 1978). Apodemus a. coreae is more infective to the Hantaan virus than to domestic animals or to other wild rodents tested (Paik, 1982).

Reproductive patterns of $A$. a. coreae, which inhabits the Korean Peninsula, were partially described, based on trapping investigations (Youngman, 1956; Won, 1961; Pelikan, 1965, 1969; Kang, 1971; Yoon et al., 1997). On the other hand, populations in the Cheju Island, classified as another subspecies, A. a. chejuensis, remain completely unstudied. Thus, the purpose of this paper is to describe characteristics of a population of A. a. chejuensis, investigating seasonal fluctuations of the population density and age structure, and seasonal changes in reproductive organs using histological and cytological

* To whom correspondence should be addressed

TEL: 2945(Ext.), E-mail. tmohri@agr. kyushu-u.ac.jp 
techniques.

\section{MATERIALS AND METHODS}

Cheju Island is located in the northern Pacific off the southern tip of the Korean Peninsula $\left(126^{\circ} 21^{\prime} \mathrm{E}\right.$ to $126^{\circ} 58^{\prime} \mathrm{E}, 32^{\circ} 50^{\prime} \mathrm{N}$ to $\left.33^{\circ} 81^{\prime} \mathrm{N}\right)$, and is the largest island in Korea (area: $1,856 \mathrm{~km}^{2}$ ). This island belongs to a subtropical oceanic climate. Monthly mean minimum temperature during the trapping period was obtained in January, $0.2^{\circ} \mathrm{C}$ in 1995 and $0.4^{\circ} \mathrm{C}$ in 1996 and maximum temperature was obtained in August, $27.7^{\circ} \mathrm{C}$ in 1995 and $26.9^{\circ} \mathrm{C}$ in 1996 . Particularly, the maximum temperature exceeded $30^{\circ} \mathrm{C}$ in July and August (Fig. 1). Fluctuating patterns of mean temperature were likely to be delayed one to two months behind those of the length of daylight, in which the maximum was $14 \mathrm{hr}$ $53 \mathrm{~min}$ in July and the minimum was $9 \mathrm{hr} 53 \mathrm{~min}$ in December. In most months, mean rain falls were less than $100 \mathrm{~mm}$, although in June and August it rained considerably and was relatively wet.

Our investigation was carried out at a point $550 \mathrm{~m}$ above the sea level on Mt. Halla $(1950 \mathrm{~m})$, which was covered with Quercus acutissima, Q. dentata, Q. serrata, Castanopsis cuspidata, Carpinus laxiflora, Pinus densiflora, and Eurya japonica. Dominant species of ground flora of this area were Sasa quelpartensis, Circaea alpina, Imperata cylindrica, and Miscanthus sinensis.

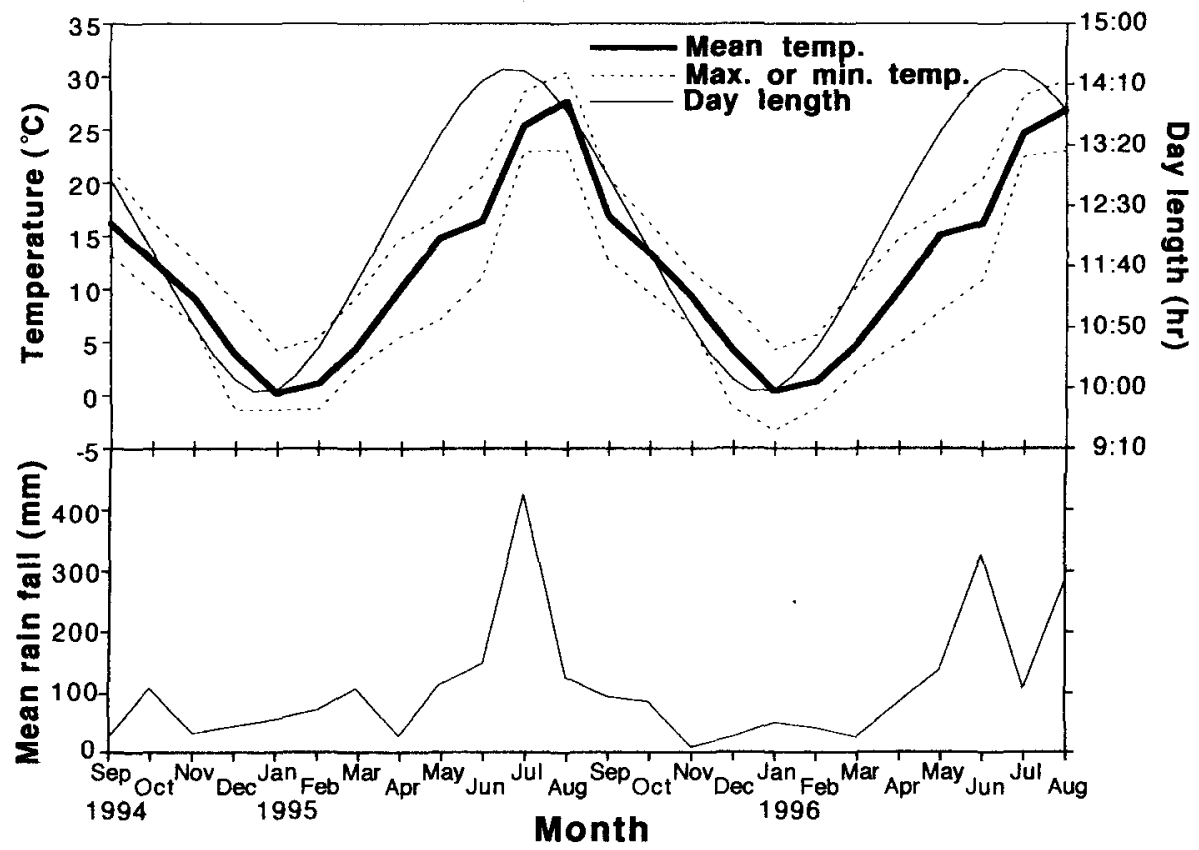

Fig. 1. Climatical informations of the studied region at the $550 \mathrm{~m}$ above the sea level on Mt. Halla, Cheju Island, Korea. 
Trapping was conducted monthly from September, 1994 to August, 1996 using 50. Sherman live traps $(5 \times 6.5 \times 16 \mathrm{~cm})$ set at $10-\mathrm{m}$ intervals in a line. Traps were set in the afternoon and checked early the next morning. Population densities were shown as the number of individuals per one hectare, based on an area of $5,000 \mathrm{~m}^{2}$ calculated by adding 5-m width strips around the trapping line. Trapped mice were weighed on an electronic balance (minimum scale: $0.01 \mathrm{~g}$ ), and their head and body, tail, hind foot, and ear lengths were measured with dial calipers (minimum scale: $0.01 \mathrm{~mm}$ ). For males, the position of testes (abdominal or scrotal) was noted, and weight and length of major or minor axis of right testes were measured on an electronic balance (minimum scale: $0.01 \mathrm{~g}$ ) and dial calipers (minimum scale: $0.01 \mathrm{~mm}$ ). Production, or lack of production, of sperm was confirmed for each testis by smears from the caudal epididymis. For females, the condition of the vagina (closed or perforated) and teats were examined, and the number of fetus was counted. Moreover, the testes, caudal epididymides and ovaries of 15 males and 15 females captured either in the breeding or non-breeding seasons were removed. These tissues were carefully cut into small pieces with a razor edge in Bouin's solution to ensure fixation of the tissues. Each tissue was fixed in solution, dehydrated and embedded in paraplast plus. Sections were cut to a thickness of $4-5 \mu \mathrm{m}$ and stained with Hematoxylin and Eosin. The process of spermatogenesis or spermiogenesis in the testes and appearance of the sperms in the caudal epididymides were observed for male samples, and changes in follicle cells in the ovaries were observed for female samples under a photomicroscope.

\section{RESULTS}

\section{Population dynamics and sex ratio}

A total of 239 mice ( 125 males and 114 females) were captured, and the sex ratio of 1.10 males per female was not significantly different from a $1: 1$ ratio $\left(\chi^{2}=0.477\right.$, $p=0.506$ ). Of those, 100 males and 87 females were adults, showing that the ratio was also not significantly different from a $1: 1$ ratio $\left(\chi^{2}=0.904, p=0.342\right)$. However, the sex ratio in each month was likely to be bias toward males (Table 1).

In the investigated population, the population densities, which had maintained a lower level during the winter (December to February), increased sharply at the beginning of spring (March) followed by a middle density period in the late spring (May to July), a temporal decrease of density in the summer (August to September), recovery a again in the autumn (October to November), and a rapid decline in the winter (Fig. 2). This seasonal changes in the population densities were significant $(F=15.16, p<0.0005)$, with higher densities in the spring and autumn than in the summer and winter.

\section{Reproductive activities of males}

All males weighed over $35 \mathrm{~g}$ captured from March to November had descended testes to scrota (Fig. 3a). On the contrary, descended testes were not observed even in individuals with normal weight (Fig. 3a). There was an apparent correlation between the position of the testes and the activity of sperm production: Of males with descended testes, $91.8 \%(78 / 85)$ had stored sperms in their caudal epididymides, while $97.5 \%$ (39/40) of males with abdominal testes had no sperm. Most individuals which had 

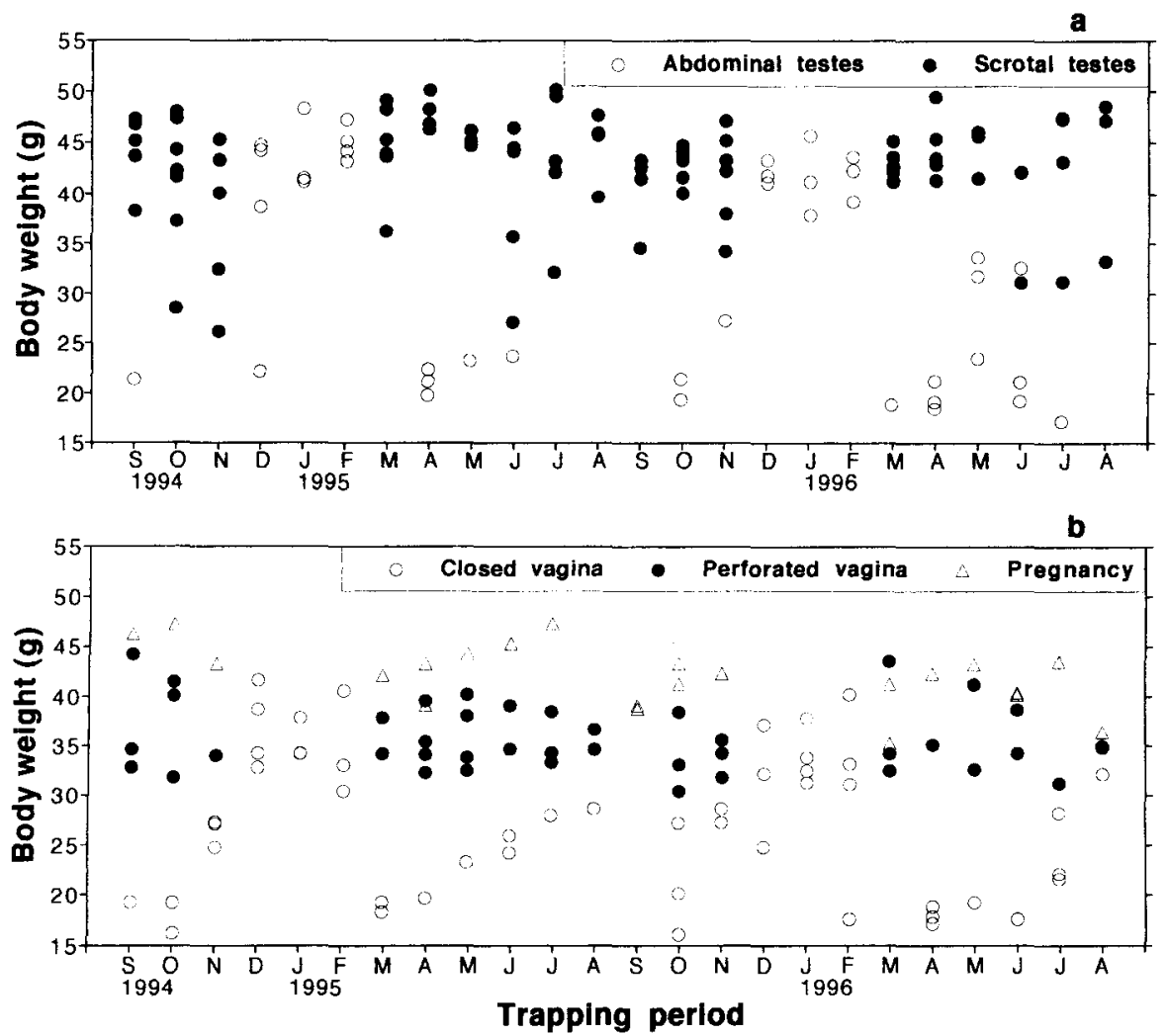

Fig. 3. Monthly distribution of a) male and b) female body weights of Apodemus agrarius chejuensis captured during the trapping period. Each symbol shows different reproductive status.

descended testes without sperm or had abdominal testes with sperms, weighed $25-35 \mathrm{~g}$, a range of body weights in subadults.

Testis weights were significantly regressed in mice captured from March to November (testis weight $(\mathrm{g})=0.148+0.025 \times$ body weight $(\mathrm{g}) ; r=0.816, F=456.5, p<0.0001$ ). Most individuals weighing $35 \mathrm{~g}$ with testis weighing over $1.02 \mathrm{~g}$ showed storage of sperms in their caudal epididymides (Fig. 4a). Although sperms were produced in males with the head and body length over $100 \mathrm{~mm}$ long with testis over $18 \mathrm{~mm}$ long in the major axis, testis length leveled off at around $20 \mathrm{~mm}$ and there was no linear relationship (Fig. 4b). Additionally, for males with an average weight over $35 \mathrm{~g}$, individuals captured from March to November ( $44.36 \pm 3.17 \mathrm{~g}, n=75$ ) were heavier than those captured from December to February ( $42.87 \pm 2.74 \mathrm{~g}, n=19, t=1.88, p=0.064$ ), while there were no significant differences in the head and body lengths (March to November: $114.01 \pm 6.49 \mathrm{~mm}$, December to February: $112.72 \pm 4.61 \mathrm{~mm}, t=0.811, p=0.42$ ). All measurements of testis size in males captured from March to November, weight (March to November: $1.27 \pm$ 


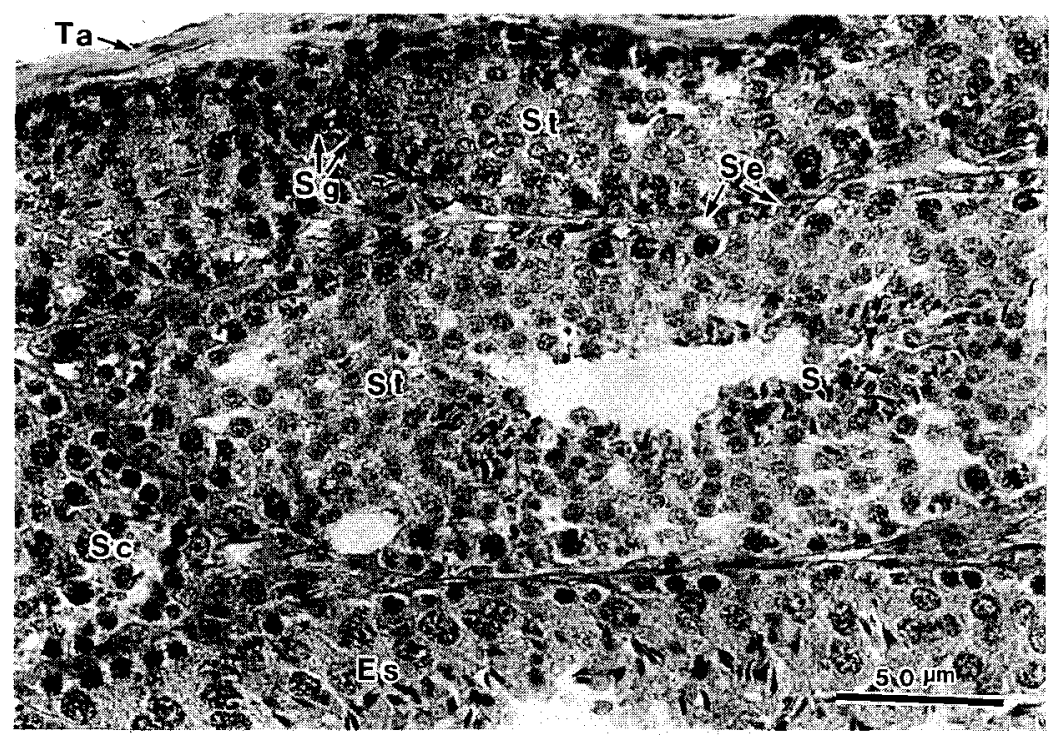

Fig. 5. Photograph of the typical testis in the non-breeding season of Apodernus agrarius chejuensis. The less acive stage in winter (January) with considerable number of spermatids and a few sperm in the slightly narrowed seminiferous tubules. Es; Elongated spermatids; S, spermatozoa; Sc, spermatocytes; Se, Sertoli cells; Sg, spermatogonia; St, spermatids; Ta, tunica albuginea.

spermatogenesis (Fig. 6a). In these periods, many spermatogonia, spermatocytes, spermatids and sperms were observed in the testes, and many sperms were observed in the caudal epididymides (Fig. 6b).

\section{Reproductive activities of females and appearance of juveniles}

Among the mice captured from March to November, almost all of the females which weighed over $30 \mathrm{~g}$ were in reproductive conditions with perforated vaginas, while for those captured from December to February, all females were not with perforated vaginas or pregnancies (Fig. 3). A total of 23 pregnant females were captured from March to November (pregnancy rate was $27.1 \%$ ), relatively remarkable in the spring (March to May) and autumn (September to November). The average number of fetus per pregnant female was $4.48 \pm 1.31$ (range: $1-7$ ). The number of fetus in the right uterine horn, $2.70 \pm 0.59$, was significantly larger than the number the left uterine horn, $1.78 \pm 0.81$ (paired $t$-test, $t=5.163, d f .=22, p<0.0001)$. These pregnant females $(42.04 \pm 3.09 \mathrm{~g})$ were significantly heavier than non-pregnant females which weighed over $30 \mathrm{~g}(35.71 \pm 3.37 \mathrm{~g}$, $n=42, t=7.45, p<0.0001$ ), while there was no significant difference between the head and body lengths (pregnant: $108 \pm 7.31 \mathrm{~mm}$, non-pregnant: $105.76 \pm 5.68, t=1.80, p=0.08$ ). There were no seasonal changes in body weights $(t=0.54, d . f=60, p=0.59)$, and head and body lengths ( $t=1.56, d f .=60, p=1.56)$ of non-pregnant females which weighed over $30 \mathrm{~g}$.

Individuals which weighed less than $25 \mathrm{~g}$ mainly appeared from March to June and October to November, so juveniles were not captured almost entirely in the summer (Fig. 3). In the summer (July and August), the number of pregnant females reduced 


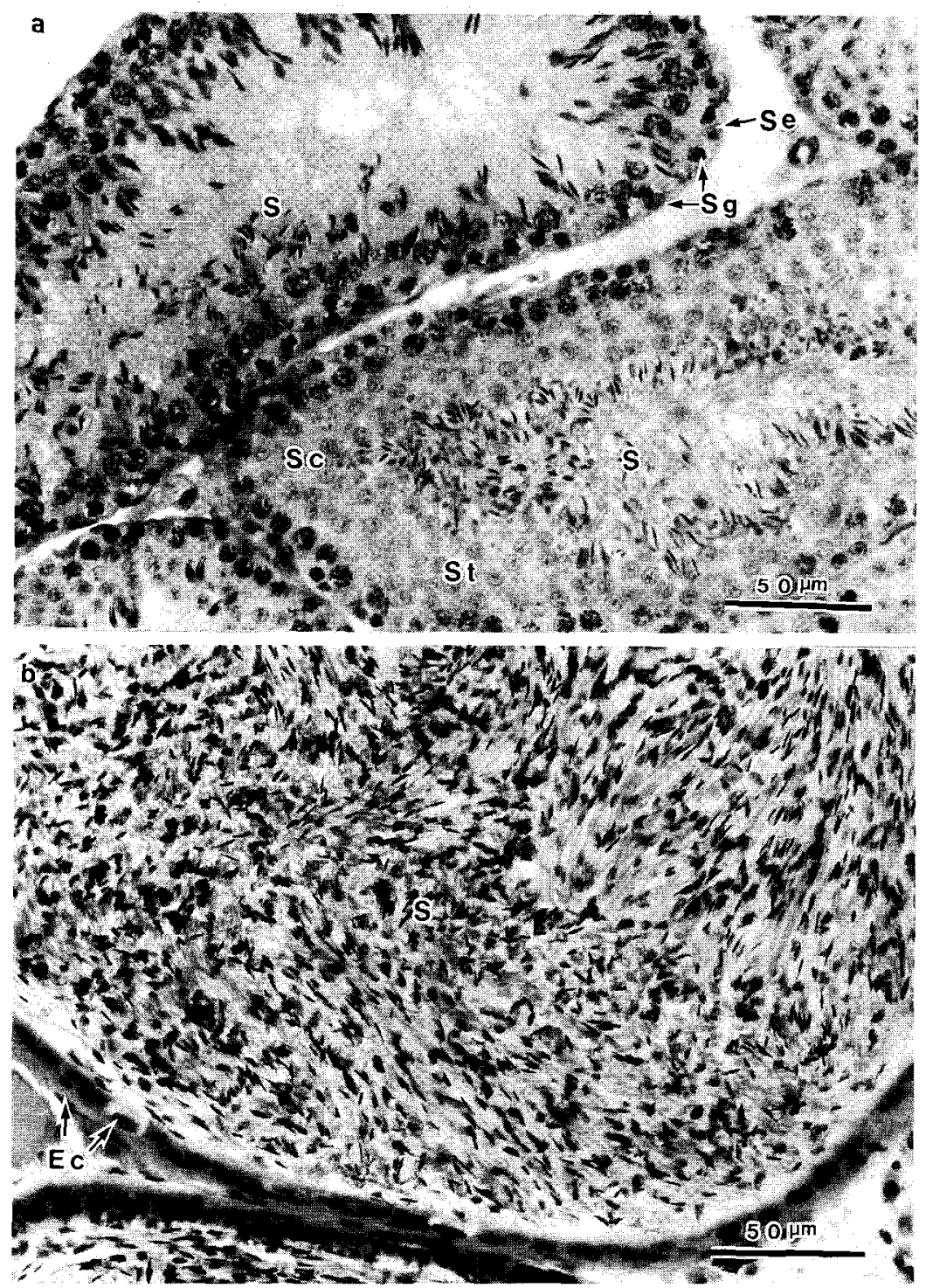

Fig. 6. Photographs of the typical testis and caudal epididymis in the breeding season of Apodemus agrarius chejuensis. a) The most active stage with the numerous sperm in the enlarged seminiferous tubules. b) The caudaepididymal tubules with numerous sperm. Ec, epithelial cells; S, spermatozoa; Sc, spermatocytes; Se, Sertoli cells; St, spermatids. 


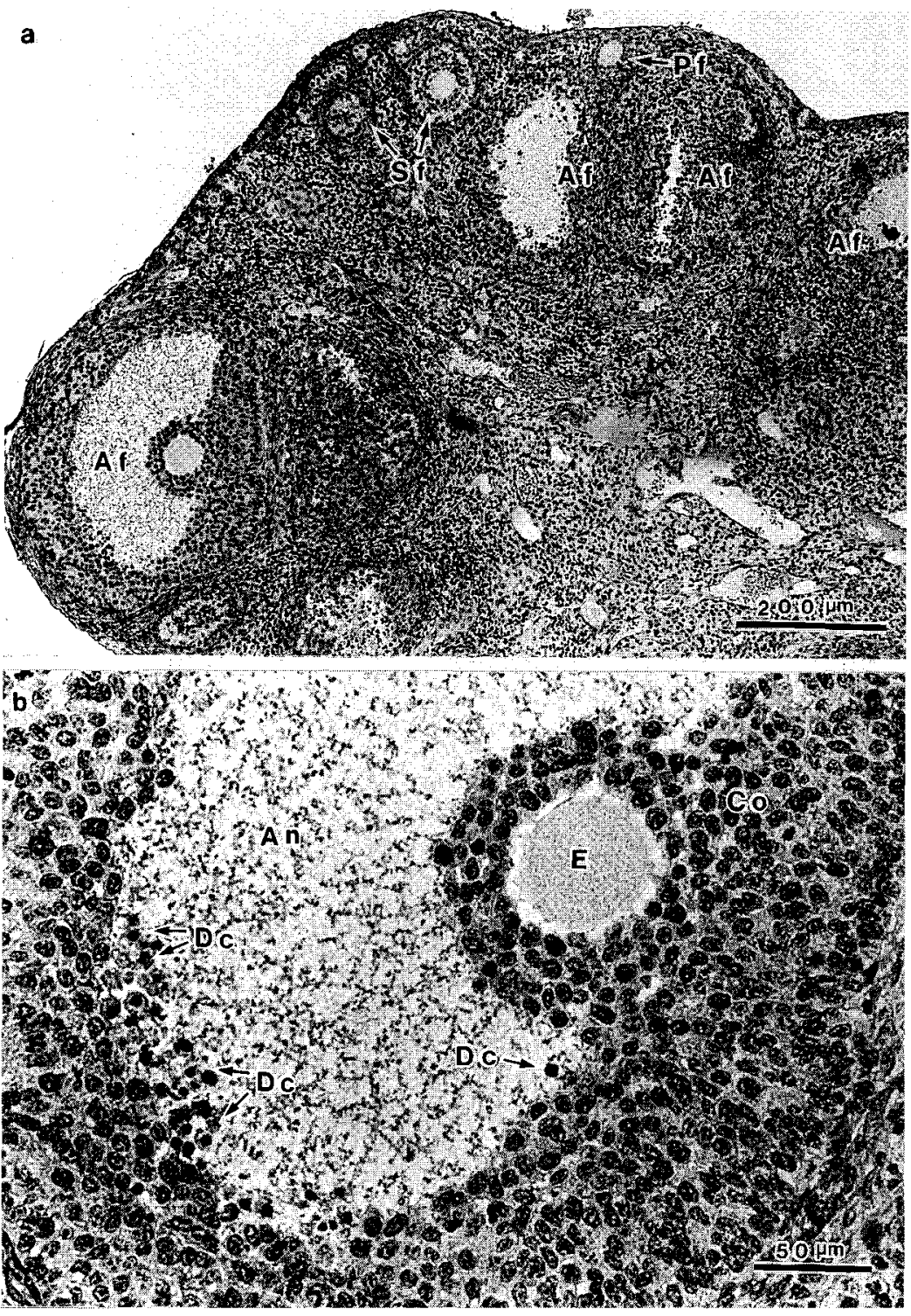

Fig.7. Photographs of the typical ovary in the non-breeding season of Apodemus agrarius chejuensis. a) Low magnification showing the ovary with atretic primary, secondary, and Graafian follicles. b) High magnification of an atretic Graafian follicle, characterized by nuclear pyknosis, hyalinized granulosa layer, and narrowed antrum. Af, atretic follicles; An, antrum; Co, cumulus oophorus; Dc, dark cells; E, egg; Pf, primordial follicles; Sf, sencondary follicles. 

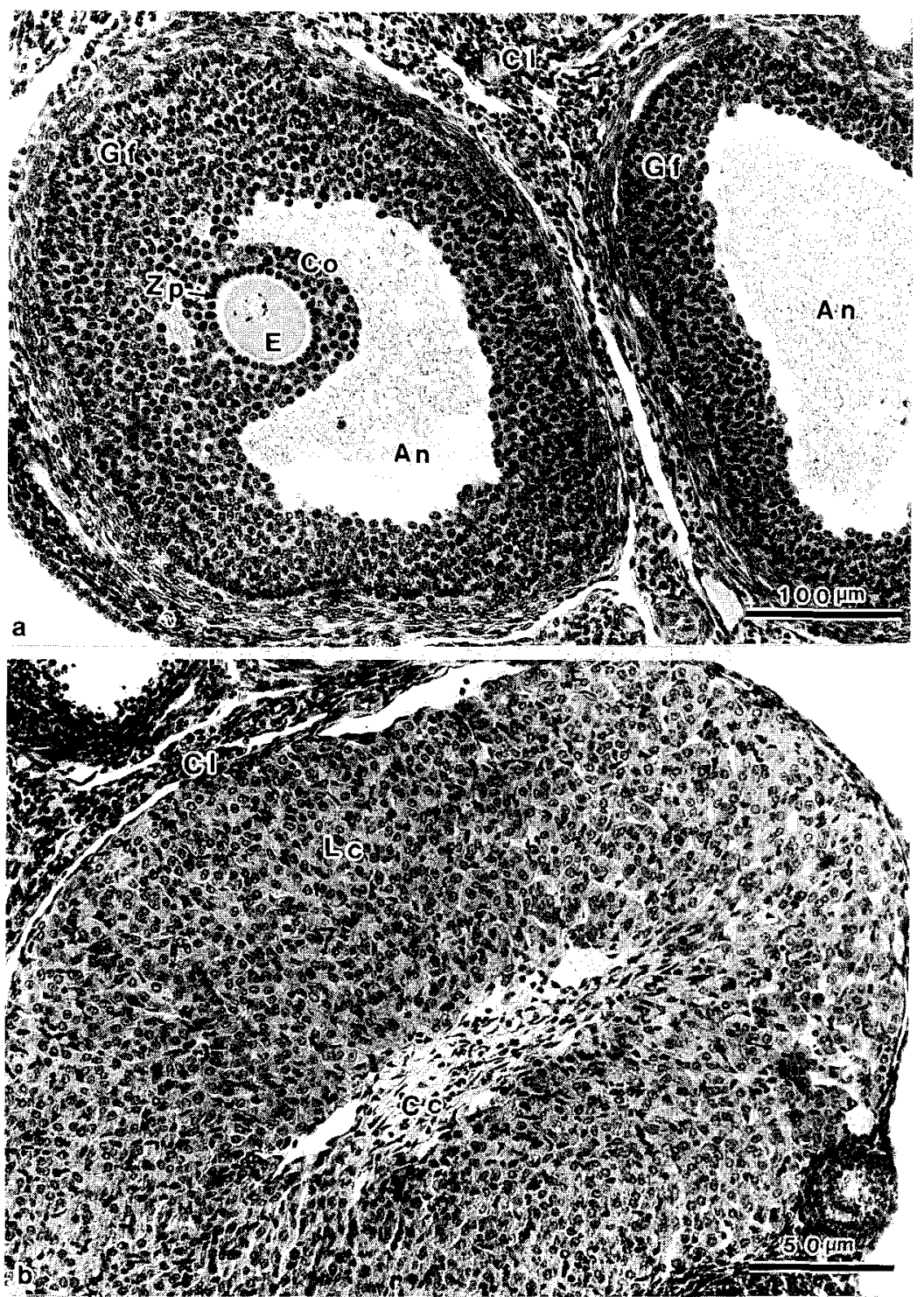

Fig. 8. Photographs of the typical ovary in the breeding season of Apodemus agrarius chejuensis. a) Graafian follicles and b) corpora lutea were observed in the same ovary. An, antrum; $\mathrm{Cc}$, connective cells; $\mathrm{Cl}$, corpus luteum; Co, cumulus oophorus; E, egg; Gf, Graafian follicle; Lc, lutein cells; $\mathrm{Zp}$, zona pellucida. 
remarkably and the total number of captured mice also decreased (Fig. 2).

Regarding seasonal changes in follicles and corpora lutea, ovaries of females captured in the winter (December to February) had a few primary, secondary, and Graafian follicles which were in atretic process of the nuclear pyknosis (Fig. 7). Females captured in the spring and autumn had ovaries with more primary follicles, secondary follicles and well-developed Graafian follicles, and corpora lutea more than those captured in the remaining seasons (Fig. 8).

\section{Sexual dimorphism in adult size}

We investigated 94 males which weighed over $35 \mathrm{~g}$ and 62 females which weighed over $30 \mathrm{~g}$ captured from March to November as adults, and compared their body weights, and head and body, tail, hind foot and ear lengths between the males and females. Mean body weights for adults were $44.06 \pm 3.13 \mathrm{~g}$ for males and $35.47 \pm 3.38 \mathrm{~g}$ for females $(t=16.25, p<0.0001$ ), and mean head and body lengths were $113.75 \pm 6.16 \mathrm{~mm}$ for males and $104.82 \mathrm{~mm}$ for females $(t=8.76, p<0.0001)$, respectively. Therefore, male adults were $24 \%$ heavier and $8 \%$ longer than female adults. Since significant differences were observed also for the tail length (male: $92.43 \pm 6.52 \mathrm{~mm}$, female: $86.95 \pm 5.68 \mathrm{~mm}, t=5.41$, $p<0.0001$ ), hind foot length (male: $22.87 \pm 0.75 \mathrm{~mm}$, female: $21.96 \pm 0.60 \mathrm{~mm}, t=8.02$, $p<<0.0001$ ), and ear length (male: $16.34 \pm 0.57 \mathrm{~mm}$, female: $15.82 \pm 0.45 \mathrm{~mm}, t=6.03, p<$ 0.0001 ), this species apparently showed male-biased sexual dimorphism in body size.

\section{DISCUSSION}

In small mammals, research on capture ratios in trapping investigations differed largely according to seasons, locations or food conditions, so those have been considered as an effective indicator representing population dynamics (Gorman, 1993; Canova et al., 1994). In a research report of year-round population dynamics in Apodemus agrarius, capture rates of juveniles were high from October to November and adults were rarely captured from November to March (Haitlinger, 1962; Hong and Lee, 1984; Yoon et al., 1997). On the other hand, $A$. a. chejuensis, which inhabits Cheju Island only, adults were captured in every season and the capture rates of juveniles increased in the spring (April to June) and autumn (September to November) which differed from A. a. coreae.

In observing the condition of vagina, appearance of pregnant females, and histological observations of the ovaries in female $A$. a. chejuensis, the breeding season was from March to November with a temporal decline of reproductive abilities in the summer. Thus, the female reproductive pattern was bimodal, similar to the pattern in appearance of pregnant females. For males, in observing the testis size, the position of the testes (abdominal or scrotal), histological observations of spermatogenesis in the testes and storage of sperms in caudal epididymides, the breeding season was essentially from March to November and the remaining seasons were non-breeding, while it was suspected that males could breed all year-round from the evidence of the presence of matured sperms in their testes even in the winter (December to February). Temperatures might effect greatly the reproductive performance of $A$. agrarius in Korea, since in the lowlands where the average temperature in January is around $7^{\circ} \mathrm{C}$ within the same Cheju Island, breeding occurred in every season (Oh, unpublished data), and in the Korean Peninsula 
with the hot summer and the cold winter, the seasonally reproductive pattern of $A$. $a$. coreae is bimodal with short breeding seasons (Yoon et al., 1997). These patterns were similar to the large Japanese field mouse, A. speciosus, which is distributed all over Japan, which changed their reproductive patterns to adopt to the climate of each region. A. speciosus breeds monomodally in the summer on Hokkaido Island, the norhernmost part of Japan, monomodally in the winter on Kyushu Island, the southernmost part of Japan, and bimodally in the spring and autumn in the middle part of Japan mainland (Abe, 1975; Kondo, 1980; Murakami, 1974). These changes in the breeding seasons also seem to have an effect on the variation of morphological characteristics. The wood mouse, $A$. sylvaticus, is known for its spermatogenesis activity in testes which declines in the winter, in which the duration of the declining period in the reproductive status of males is shorter than that of females (Crawley, 1970; Watts, 1970; Green, 1979; Montgomery, 1980).

In many mammals, the reproductive activities are adjusted to a particular season by environmental cues which ensure that the young are born at the most favorable time (Sadleir, 1972). The availability of adequate food is the primary ultimate factor driving seasonal reproduction (Bronson and Perrigo, 1987). Sexual maturity may be generally affected by both the temperature and photoperiod, in particular, phogoperiod is considered as a main factor regulating seasonal cycles of reproduction (Clarke, 1985). Winter termination of reproduction observed in $A$. a. chejuensis may be caused by such photoperiodic effects of short daylight hours as well as restriction of growth in vegetation resulting from low temperatures and enlarged requirements of thermoregulation. Moreover, the decline of breeding rates in the summer observed in this species is considered to be caused by the high temperature in the summer of the studied area which affects the reproduction ability of females.

Males weighing over $35 \mathrm{~g}$ and females weighing over $30 \mathrm{~g}$ should be considered as a population of $A$. a. chejuensis adults in this study. These adults are apparently sexually dimorphic in all of the measurements of body size. In Apodemus species, sexual dimorphism in adult body size is not observed in the small Japanese field mouse, $A$. argenteus (Koyama, 1994), while it is observed in the Formosan wood mouse, $A$. sémotus (Lin et al., 1993) and the large Japanese field mouse, A. speciosus (Oh and Mori, submitted for publication). Sexual dimorphism in mammals was suggested to be correlated with the type of social organization (Kleiman, 1977), although more researche should be conducted to clarify whether such a correlations is present in Apodemus species or not.

\section{REFERENCES}

Abe, H. 1975 Present status and problems on the natural history studies of Japanese small mammals. Mammalian Science, 31: 59-80 (in Japanese)

Bronson, F. H. and G. Perrigo 1987 Seasonal regulation of reproduction in muroid rodents. Amer. Zool, 27: $929-940$

Canova, L., L. Maistrello and D. Emiliani 1994 Comparative ecology of the wood mouse, Apodemus sylvaticus in two differing habitats. Z. Saugetierkunde, 59: 193-198

Clarke, J. R. 1985 The reproductive biology of the bank vole (Clethrionomys glareolus) and the wood mouse (Apodemus sylvaticus). Symp. Zool. Soc. Lond., 55: 33-59

Corbet, G. B. and J. E. Hill 1991 A World List of Mammalian Species. 3rd ed. Oxford University Press, 
Oxford

Crawley, M. C. 1970 Some population dynamics of the bank vole, Clethrionomys glareolus and the wood mouse, Apodemus sylvaticus in mixed woodland. J. Zool. Lond, 160: 71-89

Gorman, M. L. and Z. A. B. M. Ahmad 1993 A comparative study of the ecology of wood mice Apodemus sylvaticus in two contrasting habitats: deciduous woodland and maritime sand-dunes. J. Zool., 229: 385-396

Green, R. 1979 The ecology of wood mice (Apodemus sylvaticus) on arable farmland. J. Zool, Lond., 188: $367-377$

Hong, H. K. and U. Y. Lee 1984 Studies on the biology of Apodemus agrarius in Korea. Thesis of Inchon Univ., 6: 417-439.

Kang, S. W. 1971 Ecological studies in the field mouse. Korean J. Zool., 14: 57-74

Kondo, N. 1980 Seasonal fluctuation of population size, activity and activity area of Apodemus speciosus ainu (Thomas) in a small stand. J. Mamm. Soc. Jap., 8: 129-138 (in Japanese with English abstract)

Koyama, S. 1994 On the growth and development of Apodemus argenteus under laboratory conditions. Honyumi Kagaku (Mammalian Science) 33: 109-122 (in Japanese with English abstract)

Lee, H. W. and P. W. Lee 1976 Korean hemorrhagic fever I. Demonstration of causative antigen and antibodies. Korean J. Int. Med, 19:371-383

Lee, H. W., P. W. Lee, I. W. Seong and D. S. Park 1978 Blood analysis of normal and infected Apodemus agrarius, natural reservoir of Korean hemorrhagic fever. Korean J. Soc. Virol, $\mathbf{8}: 21-27$

Lin, L-K., T. Nishino and S. Shiraishi. 1993 Postnatal growth and development of the Formosan wood mouse, Apodemus semotus. J. Mamm. Soc. Japan, 18: 1-18

Montgomery, W. I. 1980 Spatial organization in sympatric populations of Apodemus sylvaticus and $A$. flavicollis (Rodentia: Muridae). J. Zool, Lond., 192: 379-401

Murakami, O. 1974 Growth and development of the Japanese wood mouse (Apodemus speciosus). I. The breeding season in the field. Jpn. J. Ecol., 24: 194-206 (in Japanese with English synopsis)

Paik, K. J. 1982 Sensitivites of various animals to the etiological agent of Korean hemorrhagic fever, Hantaan virus. J. Med., Korea Univ., 19: 35-41

Pelikan, J. 1965 Reproduction, population structure and elimination of males in Apodemus agrarius. Zool. Listy, 14: 317-332

Pelikan, J. 1969 Notes on reproduction and sex ratio on Apodemus agrarius (Pall.). Lynx., 6: 121-124

Sadleir, R. M. F. S. 1972 Environmental effects. In "Reproduction in Mammals", 4th ed. (Austin, C. R. and R. V. Short, eds.), Cambridge Univ. Press, New York, pp. 69-3

Watts, C. H. S. 1970 Effects of supplementary food on breeding in woodland rodents. J. Mamm., 51: $169-171$

Won, P. H. 1961 Studies on the ecological observation of Rodentia in Manchuria and Korea. PL. I. Zool. Inst., Liberal Arts coll., Dong Kook Univ., Seoul, 1-92

Yoon, M. H., S. J. Jung and H. S. Oh 1997 Studies on population structure and reproductive pattern of the Korean striped field mice, Apodemus agrarius. Korean J. Biol. Sci., 1: 53-61

Youngman, P. M. 1956 A population of the striped field mouse, Apodemus agrarius coreae, in central Korea. J. Mamm., 37; 1-10 